\title{
鼻副鼻腔乳頭腫における基部推定についての検討
}

\author{
吉田 充裕, 佐藤 進一 \\ 大原記念倉敷中央医療機構倉敷中央病院耳鼻咽喉科·頭頸部外科
}

\begin{abstract}
鼻副鼻腔内反性乳頭腫は良性腫瘍であるにも関わらず，再発，癌化の可能性がある。そして腫瘍の再発のほ とんどは不完全な切除による腫瘍の遺残が原因である。腫瘍再発の頻度を減少させるためには腫瘍の完全摘出 が必要となる。そのためには, 術前に画像検査で腫瘍基部を診断し，適切な術式を選択することが望ましい。 これまでに, CT画像での骨肥厚や骨萎縮所見, MRI画像での脳回様パターン (Convoluted cerebriform pattern: CCP）の集簇所見から腫瘍基部を推定できることが報告されている。今回, CT画像での骨肥厚または骨萎縮部 位, MRI画像でのCCP集簇部位を腫瘍基部と推定した。CT画像では骨条件のみを用いた報告が多いが, 本検討 では通常条件も用いることで高率（83.3\%）に正確な腫瘍基部の推定が可能であった。腫瘍基部推定における CT通常条件画像の有用性について症例を提示して報告する。
\end{abstract}

キーワード：鼻副鼻腔内反性乳頭腫，腫瘍基部，CT, 骨条件, 通常条件

\section{Predicting the Site of Attachment of Sinonasal Inverted Papilloma}

\author{
Atsuhiro Yoshida, Shin-ichi Sato \\ Department of Otolaryngology-Head and Neck Surgery, \\ Kurashiki Central Hospital, Ohara Health Care Foundation
}

Sinonasal inverted papilloma (SNIP), a benign tumor, demonstrates a high recurrence rate after surgery. Since the recurrence is not caused by tumor dissemination but by the tumor remnant, precise localization and excision of the originating site of a SNIP is essential. Therefore, it is important to precisely define prior to surgery the tumor margins with both computed tomography $(\mathrm{CT})$ and magnetic resonance imaging (MRI).

It has been reported that the site of SNIP attachment can be defined prior to surgery based on either CT scans using bone osteitic changes as an indicator or MRI with convoluted cerebriform pattern (CCP)-based reverse tracing.

In this study, we defined the site of SNIP attachment mainly based on CT scans using bone osteitic changes as an indicator or MRI with convoluted CCP-based reverse tracing. It was possible to define the originating site of the tumor at a high rate using not only bone windows but also standard windows in the CT scans. We found that standard windows in the CT scans were effective. We present some cases and explain their usefulness.

Key words : Sinonasal inverted papilloma, Originating site of tumor, CT, Bone window, Standard window (2019年5月 23 日受稿, 2020 年 9 月 17 日受理) 


\section{はじめに}

鼻副鼻腔内反性乳頭腫は良性腫瘍であるにも関わら ず，再発や癌化の可能性があるため, 腫瘍の完全摘出が 必要とされている。術前の画像検査から腫瘍基部を正確 に診断することができれば，手術計画を適切に立てるこ とが可能となり，腫瘍の完全摘出も容易になると考えら れる。これまでに，CTでの骨肥厚や骨萎縮所見，MRIで の脳回様パターン (Convoluted cerebriform pattern: 以 下CCP）の集簇所見から腫瘍基部を推定できることが報 告されている ${ }^{1,2)}$ 。今回, 当科で行った内反性乳頭腫手術 症例を用いて，CTでの骨肥厚や骨萎縮所見，MRIでの CCPの集簇所見からの腫瘍基部推定の精度について検討 を行った。一部の症例について腫瘍基部推定の過程を示 し，結果について報告する。

\section{対象}

2015年〜2018年に当科で手術を行った鼻副鼻腔内反性 乳頭腫症例は 20 例であった。20例中, 腫瘍基部について の手術記録の記載が不十分であった 6 例, 腫瘍基部につい ての記載はあったが腫瘍再発部位などから後ろ向きにみて
記載された腫痬基部が誤りであると判断した 2 例は除外 し，残る 12 例について検討した。尚，本研究は「人を対 象とする医学系研究に関する倫理指針」に沿って倉敷中 央病院倫理委員会の承認を得て行われた(承認番号3459)。

\section{方法}

腫瘍基部推定方法

1)CTからの腫瘍基部の推定

術前CTの骨条件・通常条件画像で骨肥厚または骨萎縮 部位を調べ，その部位を腫瘍基部と推定した。骨条件は window width $1500 \mathrm{HU}$, window level $300 \mathrm{HU}$, 通常条件 はwindow width $300 \mathrm{HU}$, window level $20 \mathrm{HU}$ とした。 (2)MRIからの腫瘍基部の推定

術前MRI T2 強調画像でCCPを認め, その集簇部位が 確認できた場合，その部位を腫瘍基部と推定した。

各種画像検査で行った腫瘍基部推定の精度

各種画像検查から推定された腫瘍基部と手術記録に記 載されている腫瘍基部の解剖学的位置を後ろ向きに比較 し, 両者の一致率を求めた。

表 1 腫瘍基部推定の根拠となった画像所見とその精度

\begin{tabular}{|c|c|c|c|c|c|c|c|c|}
\hline \multirow{3}{*}{ 症例 } & \multicolumn{3}{|c|}{$\mathrm{CT}$} & \multirow{3}{*}{$\frac{\text { MRI }}{\text { CCP集簇 }}$} & \multirow{3}{*}{ 推定基部 } & \multirow{3}{*}{ 確認基部 } & \multirow{3}{*}{$\begin{array}{c}\text { 推定基部/確認基部 } \\
\text { の一致 }\end{array}$} & \multirow{3}{*}{ 備考 } \\
\hline & \multicolumn{2}{|c|}{ 骨肥厚 } & \multirow{2}{*}{ 骨破壊 } & & & & & \\
\hline & 骨条件 & 通常条件 & & & & & & \\
\hline 1 & $\bigcirc$ & $\bigcirc$ & - & $\times$ & agger nasi cell & agger nasi cell & $\bigcirc$ & 再発症例 \\
\hline 2 & ○ & $\bigcirc$ & - & $\triangle$ & 第3基板上方 & 涙骨～紙様板 & $\times$ & $※ 1$ \\
\hline 3 & $\bigcirc$ & $\bigcirc$ & - & $\times$ & 第 2 基板上端 & 第 2 基板上端 & $\bigcirc$ & \\
\hline 4 & - & - & $\bigcirc$ & $\bigcirc$ & 上顎洞内側壁後方 & 上顎洞内側壁後方 & $\bigcirc$ & \\
\hline 5 & $x$ & $\bigcirc$ & - & $\times$ & 篩骨胞 & 篩骨胞 & $\bigcirc$ & \\
\hline 6 & $x$ & $\bigcirc$ & - & $\times$ & 鉤状突起 & 鉤状突起 & $\bigcirc$ & \\
\hline 7 & O & $\bigcirc$ & - & $\times$ & 上顎洞前壁～外側壁～後壁 & 上顎洞前壁 & $x$ & 再発症例 ※2 \\
\hline 8 & $x$ & $\bigcirc$ & - & $\triangle$ & 第3基板下方 & 第3基板下方 & $\bigcirc$ & \\
\hline 9 & $\times$ & O & - & $\bigcirc$ & 鉤状突起 & 鈎状突起 & $\bigcirc$ & \\
\hline 10 & 0 & $\bigcirc$ & - & 未施行 & 上顎洞後壁内側 & 上顎洞後壁内側 & $\bigcirc$ & \\
\hline 11 & $x$ & $\bigcirc$ & - & $\triangle$ & 上鼻甲介内側後方 & 上鼻甲介後方 & $\bigcirc$ & \\
\hline 12 & $\bigcirc$ & 0 & - & $\times$ & 後部篩骨洞隔壁 & 後部篩骨洞隔壁 & $\bigcirc$ & \\
\hline
\end{tabular}

CT骨条件，MRIと比較し，CT通常条件で高率に腫瘍基部が推定できた。

症例 7 はCT骨条件，通常条件ともに骨肥厚を認めたものの，骨肥厚が広範囲に及び腫瘍基部が推定できなかった。骨肥厚は慢 性炎症や術後性変化によるものと考えられた。

MRIでは症例 1,10 を除く全例でCCPを認めたが, CCPの集簇部位を確認できたものは多くなかった。MRI単独でCCPの集簇部 位を指摘できた症例を○で，MRI単独ではCCPの集簇部位を指摘できなかったがCTでの腫瘍基部推定後に同部にCCPが集簇して いると認識できた症例を $\triangle て ゙$ 示した。

வはCTで腫瘍基部推定後にMRIを見るとCCP集簇を認識できた症例

※1 実際の腫瘍基部はCT通常条件でのみ骨肥厚を認めた

※2 骨肥厚が広範囲に認められ腫瘍基部の推定が困難であった 


\section{結果}

1）術前 CT, MRIの施行の有無

CTは 12 例全例で術前に施行されていた。MRIは術前 に乳頭腫と診断されていた11例で術前に施行されていた が，術前に真菌症と診断されていた 1 例については未施 行であった。

2) 術前診断

術前診断は 12 例中 11 例で乳頭腫， 1 例で真菌症と診断 されていた。真菌症と診断された 1 例は鼻腔腫瘤生検で ポリープと診断され，画像検査としてCTのみを施行し， MRIを施行して扔らず，陰影内の石灰化をみて真菌症と 診断されていた。

3）術前基部推定（表1）

CTでは 12 例中 10 例で骨肥厚部位を腫瘍基部と推定, 1 例で骨破壊部位を腫瘍基部と推定した。残る 1 例は再発 症例であり，慢性炎症あるいは術後変化によると考えら れる広範囲の骨肥厚のためCTでの腫瘍基部推定が困難 であった。骨肥厚部位を腫瘍基部と推定した10例のうち， CT骨条件で明らかな骨肥厚を認めた症例は5例であった のに対して，CT通常条件では 10 例全例で明らかな骨肥 厚を認めた。MRIでは検查を行った11例中10例でCCPを 認めたが，再発症例の 1 例では腫瘍サイズが小さくCCP を認めなかった。CCPを認めた10例のうちMRI単独で $\mathrm{CCP}$ 集簇部位が確認できた症例は 2 例で, CTで腫瘍基部 推定後にMRIをみると同部へのCCP集簇を認識できた症 例が3例あった（ $\triangle$ 印）。

4）各種画像から推定した腫瘍基部と手術所見で認めた 腫瘍基部の一致率（表1）

今回検討した 12 症例について, 術前の各種画像検查か ら推定した腫瘍基部と術中所見で認めた腫瘍基部の一致 の有無を確認した。

CTでは 12 例中 10 例（83.3\%）で一致し, 2 例（16.7\%）
で一致しなかった。一致した 10 例のうち，9例は骨肥厚 部位が腫瘍基部であり，1例は骨破壊部位が腫瘍基部で あった。一致しなかった 2 例のうち，1例（症例7）は上 顎洞乳頭腫の再発症例であり，上顎洞壁の広い範囲に骨 肥厚が認められ，腫瘍基部の推定が困難であった。一致 しなかった残る1例（症例2）は骨肥厚部位が2か所あり, 腫瘍基部と推定した骨肥厚部位とは異なる方の骨肥厚部 位が実際の腫瘍基部であった。また骨肥厚部位を腫瘍基 部と推定し実際の腫瘍基部と一致した 9 例のうち, CT骨 条件で骨肥厚を認めた症例は9例中 4 例であったのに対し て，CT通常条件では 9 例全例で骨肥厚を認めた。骨肥厚 が2か所あり腫瘍基部を誤って推定した症例 2 において も, 実際の腫瘍基部はCT通常条件では骨肥厚として認め られるものの, CT骨条件では骨肥厚と認識できない部位 であった。

MRI単独でCCP集簇を確認できた 2 例中 2 例，CTで腫 瘍基部推定後にMRIをみると同部へのCCP集簇を認識で きた3例中2例で推定した腫瘍基部と実際の腫瘍基部が一 致していた。しかし，CCP集簇部位が確認できない症例 が 7 例あり，全体的には，一致したものは 11 例中 4 例 (36.4\%) であった。

6) 症例提示

以下CTやMRIで腫瘍基部の同定が容易であった症例 や，困難であった症例を提示する。

症例 5：CTの通常条件が分かりやすかった症例（図 1)

CTの通常条件で右穊骨胞に骨肥厚を認め, 腫瘍基部と 推定した。骨条件では骨肥厚が明らかでなかった。MRI ではCCPの集簇は明らかでなかったが，同部に均一な low intensity areaを認めた。術中所見でも同部に腫瘍基 部を認めた。本症例ではCTの通常条件が骨条件より有用 であった。

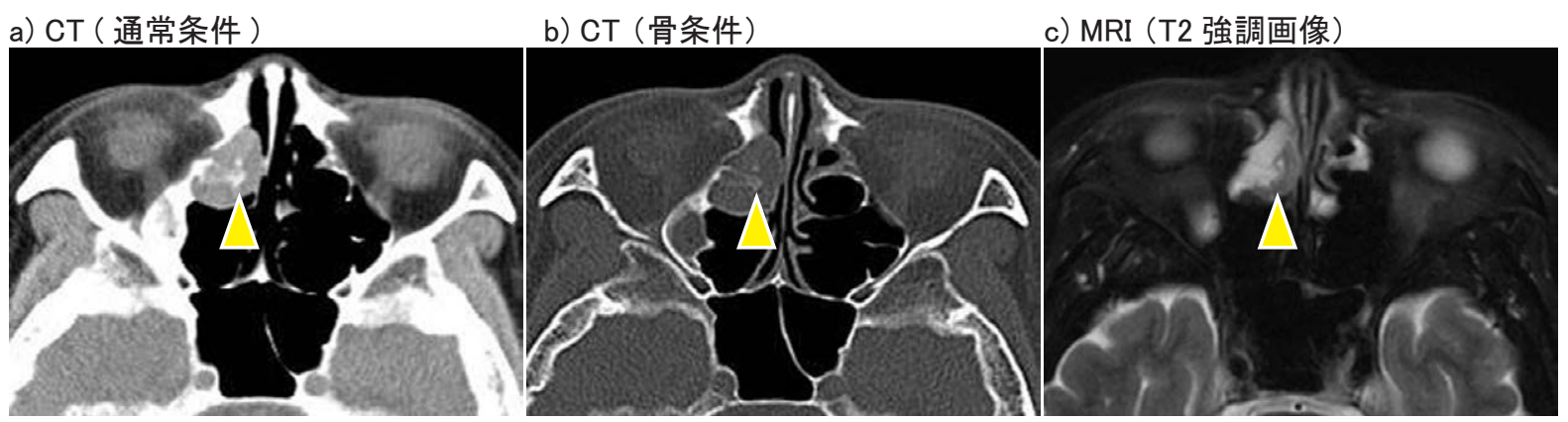

図1CTの通常条件が分かりやすかった症例（症例 5)

CTの骨条件では骨肥厚が目立たないが, 通常条件では明らかに骨肥厚を認めた (矢頭)。同部はMRIで均一なlow intensity areaを認めた。骨肥厚部位の推定に骨条件よりも通常条件が有用であった。 
症例 10 ：慢性炎症性骨肥厚を伴う症例（図 2)

本症例は術前にMRIを施行しておらず真菌症と診断さ れていた症例である。術中標本の永久病理で内反性乳頭 腫と診断された。診断が確定した後に術前CTを確認した ところ, CT通常条件で右上顎洞後壁内側に上顎洞内に突 出する骨隆起を認め, 腫瘍基部と推定できた。CT骨条件 では骨隆起は目立たなかった。再手術時に腫瘍基部が上 顎洞後壁内側にあることを確認した。

症例 4 ：骨萎縮部位が基部であった症例（図3）

左右の上顎洞を比較して患側（左側）での明らかな骨 肥厚は認められなかったが, 左上顎洞内側壁後方に骨萎 縮を認めた。MRIで同部にCCPの集簇を認め，腫瘍基部 と推定した。手術所見でも腫瘍基部を同部に認めた。今 回の検討では骨萎縮から腫瘍基部を推定した唯一の症例 であった。

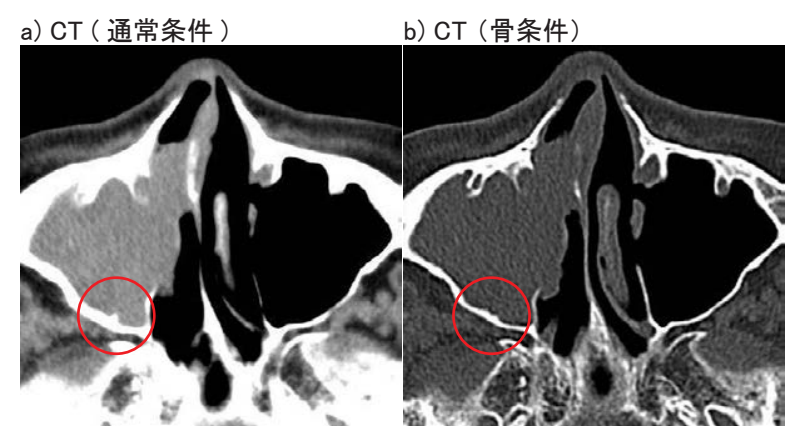

図2 慢性炎症性骨肥厚を伴う症例（症例 10）

慢性炎症を反映して右上顎洞後壁の骨は全体的に肥厚 を認めた。全体的な骨肥厚のために基部の推定が困難 であることもあるが, この症例ではCTの通常条件で上 顎洞後壁内側に上顎洞内に突出する骨隆起を認め（赤 丸), 腫瘍基部と推定できた。この症例でもCTの通常 条件が有用であった。術前にはMRIを撮影しておらず 真菌症と診断されていた。
症例 2 : 複数の腫瘍基部が疑われ, 腫瘍基部を正しく推 定できなかった症例（図4)

右後部篩骨蜂巣にCTの通常条件, 骨条件でともに目立 つ骨肥厚を認めた。また右前篩骨蜂巣にCTの通常条件で 目立つが骨条件では目立たない骨肥厚を認めた。CT骨条 件でも骨肥厚を認める右後部篩骨蜂巣の骨肥厚部位を腫 瘍基部と推定した。MRI単独でのCCPの集簇部位は確認 できなかったが，CTで腫瘍基部推定後にMRIをみると CCP集簇は右後部篩骨蜂巣でも矛盾しないように思え た。しかし，手術所見では腫瘍基部は前篩骨蜂巣の骨肥 厚部位であった。後ろ向きにみるとMRI（T2 強調画像） で前篩骨蜂巣にlow intensityの部位を認め, 同部にCCP が集簇していると考えるのが妥当であった。

\section{考察}

鼻副鼻腔内反性乳頭腫は同時性または異時性に悪性腫 瘍を伴うことがあり, 完全切除が必要な疾患である ${ }^{3)}$ 。し かし, 術後再発率は高いことが報告されている（再発率 15-25.3\% $\left.{ }^{4 \sim 6)}\right)$ 。ほとんどの場合，再発部位は手術時に同 定された腫瘍基部と同じであり，不完全な腫瘍切除によ る再発であると推測される ${ }^{7)}$ 。腫瘍の完全切除には腫瘍 基部の適切な処理が必要であり, そのためには, 鼻副鼻 腔解剖の理解と術前の腫瘍基部の推定が重要である。

今までも，術前の画像検査から腫瘍基部を推定する方 法が報告されている。CT画像で骨肥厚や骨萎縮部位を腫 瘍基部と推定する方法 ${ }^{1)}$ や, MRIの T2 強調画像や造影 $\mathrm{T} 1$ 強調画像でCCPの集簇する部位を腫瘍基部と推定する方 法などである ${ }^{2)}$

今回の検討ではCT画像での骨肥厚または骨萎縮部位 を腫瘍基部と推定することで，12例中 10 例（83.3\%）と 高率に腫瘍基部を予測することができ，その10例のうち

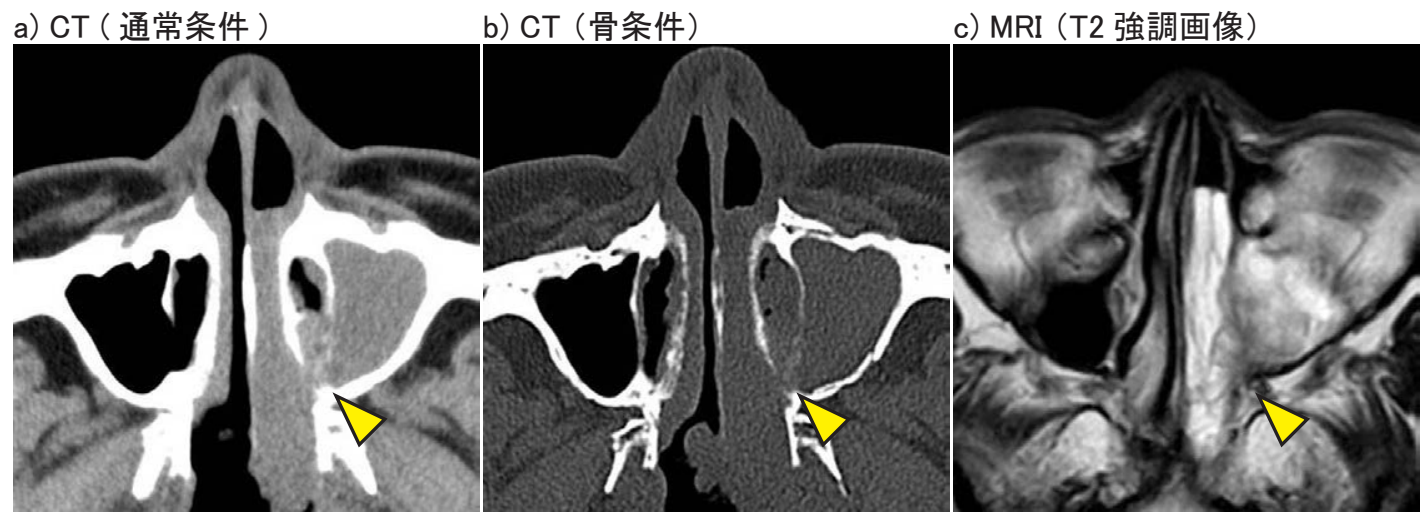

図3 骨破壊部位が基部であった症例（症例4）

CTの通常条件，骨条件で左上顎洞の内側壁後方に骨萎縮を認めた。MRIで同部にCCPの集簇を認め，腫瘍基部と推定した (矢頭)。今回の検討では骨破壊部位から腫瘍基部を推定した唯一の症例であった。 


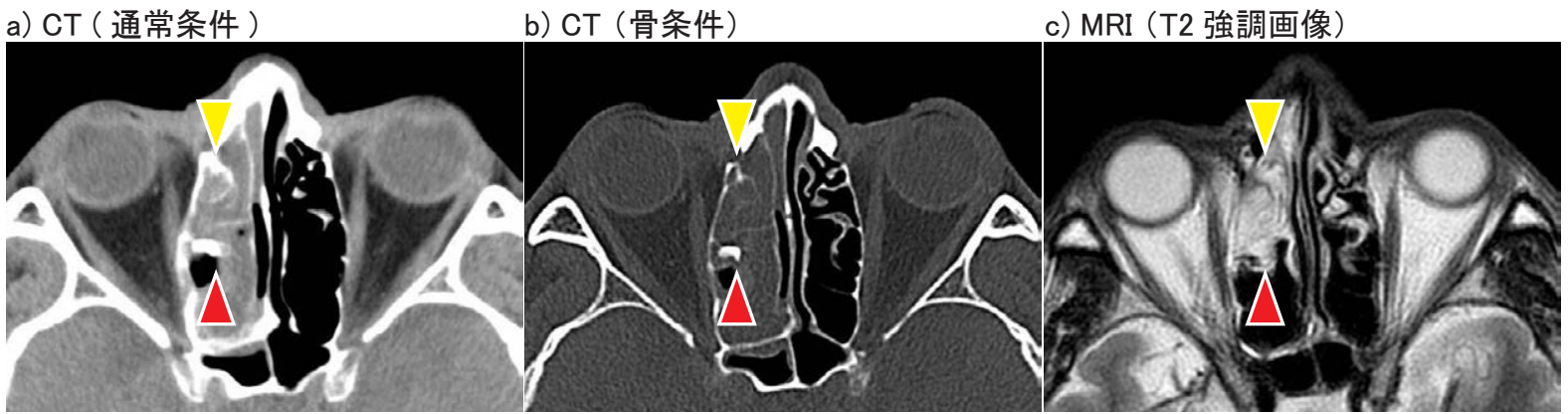

図4＼cjkstart複数の基部が疑われ，基部を正しく推定できなかった症例（症例 2）

CT骨条件，通常条件で骨肥厚の目立つ後部篩骨蜂巣の部位（赤色矢頭）を基部と推定したが，手術所見では通常条件での み骨肥厚が目立つ前部篩骨蜂巣の部位（黄色矢頭）が基部であった。この症例でもCT通常条件の骨肥厚が腫瘍基部推定に 有用であった。MRI T2 強調画像でもlow intensity area（黄色矢頭）を腫瘍基部と考えるのが妥当であった。

9例は骨肥厚部位を腫瘍基部と推定したものであった。そ の9例のうちCT骨画像で骨肥厚を認めたものは5例で あったのに対して, CT通常条件では 9 例全例で骨肥厚を 認めた。また, CT骨条件では骨肥厚を認めず腫瘍基部の 推定を誤ったが, CT通常条件では実際の腫瘍基部に骨肥 厚を認める症例もあった。

CT画像での骨肥厚や骨萎縮から推測した腫瘍基部と, 術中に確認した腫瘍基部を比較したこれまでの報告での 両者の一致率は41 95\% 1,2.89)であった。これらの報告で 用いられたCT画像の条件と腫瘍基部予測的中率につい て比較したところ, CT骨条件画像のみを用いた報告では 予測的中率が $\left.41 \%^{8} ， 64 \%{ }^{9}\right)$ であったのに対して，CTの骨 条件画像とともに通常条件画像を用いた報告では予測的 中率が $95 \%{ }^{1}$ であった。今回の検討でも, CT骨条件画像に 加え通常条件画像を用いることで腫瘍基部の推定が容易 となった症例が5例あった。我々は腫瘍基部推定に通常条 件画像を使用することを推奨するとの見解 ${ }^{1}$ を支持する。

MRI画像で推定した腫瘍基部と術中に確認した腫瘍基 部の比較には，予測的中率は $84.1 \%$ とする報告 ${ }^{2}$ がある。 この報告では，CCPを追跡することで均一な信号となる 部位を探し基部と推測する方法とともに，CCPを追跡で きない症例では骨肥厚による低信号部位を腫瘍基部と推 定する方法が用いられていた。 Iimuraらは上顎洞乳頭腫 に限定した検討ではあるが，CCPの集簇部位を腫瘍基部 と推測する方法での予測的中率を $38 \%$ としている ${ }^{10)}$ 。こ の報告では腫瘍が小孔を通過する部位でCCPが集簇する ように見え腫瘍基部が正しく推定できなかった可能性が あることや，典型的なCCPを認めない症例が少なからず 存在したことなどについて言及されている。この報告と 同様に，今回の検討でも MRI画像のみでCCPの集簇部位 を評価することが困難であった。しかし，CT画像で腫瘍 基部を推定した後にMRIをみるとCCPの集簇を認識でき
る症例もあった。また骨肥厚が複数ある症例が多い ${ }^{8}$ との 報告もあり，MRI画像でのCCP集簇の有無を確認するこ とで, CT画像で認めた複数ある骨肥厚部位から腫瘍基部 候補を限定することができると考えられた。腫瘍基部推

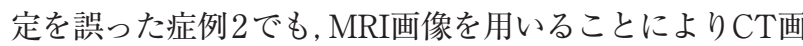
像での 2 か所の骨肥厚部位からどちらが腫瘍基部である かを正確に推定できたと考えられた。その際，CCPの集 簇部位がMRI T2強調画像で均一なlow densityになること を熟知している必要があった。

これらのことから,まずCT画像での骨肥厚または骨萎 縮部位を腫瘍基部と推定し，複数の腫瘍基部の候補があ る場合にはMRI画像でCCPの集簇が認められる部位を確 認するのが妥当であると考えた。

また, 術前画像検査で高率に腫瘍基部の推定が可能で あったことから，術前カンファレンスなどでの十分な画 像読影が重要と考えられた。

$$
\text { まとめ }
$$

術前のCT画像, MRI画像を用いることで高率 $(83.3 \%)$ に鼻副鼻垫内反性乳頭腫の基部を推定することが可能で あった。CT画像では骨条件のみでなく通常条件も用いる ことで効率的に腫瘍基部の推定ができた。

\section{参考文献}

1) Bhalla RK, Wright ED: Predicting the site of attachment of sinonasal inverted papilloma. Rhinology 2009; 47: 345-348.

2) Fang G, Lou H, Yu W, et al: Prediction of the originating site of sinonasal inverted papilloma by preoperative magnetic resonance imaging and computed tomography. Int Forum Allergy Rhinol 2016; 6: 1221-1228. 
3）中丸裕爾：鼻副鼻胿良性腫瘍. JOHNS 2017; 33: 891894.

4) Busquets JM, Hwang PH: Endoscopic resection of sinonasal inverted papilloma. Otolaryngol Head Neck Surg 2006; 134: 476-482.

5) Peng P, Har-El G: Management of inverted papillomas of the nose and paranasal sinuses. Am J Otolaryngol 2006; 27: 233-237.

6) Nygren A, Kiss K, von Buchwald C, et al: Rate of recurrence and malignant transformation in 88 cases with inverted papilloma between 1998-2008. Acta Otolaryngol 2016; 136: 333-336.

7) Krouse JH: Endoscopic treatment of inverted papilloma: Safety and efficacy. Am J Otolaryngol 2001; 22: 87-99.

8) Al Badaai Y, Chankowsky J, Mah M, et al: Radiological localization of Schneiderian papilloma. Inf Forum Allergy Rhinol 2011; 1: 488-491.

9) Lee DK, Chung SK, Dhong HJ, et al: Focal hyperostosis on $\mathrm{CT}$ of sinonasal inverted papilloma as a predictor of tumor origin. AJNR Am Neuroradiol 2007; 28: 618-621.

10) Iimura J, Otori $\mathrm{N}$, Ojiri $\mathrm{H}$, et al: Preoperative magnetic resonance imaging for localization of the origin of maxillary sinus inverted papillomas. Auris Nasus Larynx 2008; 36: 416-421. 